\title{
LOWER- TO MIDDLE PLEISTOCENE FLANK MARGIN CAVES AT CUSTONACI (TRAPANI, NW SICILY) AND THEIR RELATION WITH PAST SEA LEVELS
}

\author{
SPODNJE DO SREDNJE PLEISTOCENSKE JAME TIPA FLANK \\ MARGIN PRI CUSTONACI (TRAPANI, SZ SICILIJA) IN \\ SPREMINJANJE MORSKE GLADINE
}

\author{
Rosario RUGGIERI ${ }^{1,2} \&$ Jo DE WAELE ${ }^{3 *}$
}

\begin{abstract}
UDC 551.435.8:551.468(450.82)"628.62"

Rosario Ruggieri \& Jo De Waele: Lower- to Middle Pleistocene flank margin caves at Custonaci (Trapani, NW Sicily) and their relation with past sea levels

The peninsula of San Vito Lo Capo, $50 \mathrm{~km}$ West of Palermo (Sicily), is characterised by the presence of a wide set of evidences of past sea level changes, such as marine terraces, notches, marine and coastal caves with phreatic overgrowths on speleothems, and continental and marine deposits. The exceptional good preservation of these landforms and deposits has been used by different authors for the reconstruction of sea level changes and neotectonic movements. Among the many caves discussed by previous authors, most are of marine origin and can preserve signs of old sea level highstands such as notches and marine or continental sediments. However, two caves in particular, Fantasma Cave and Falesia Rocca Rumena I cave, show evidences to be flank margin caves. Both caves are records of rising and falling sea level, and their position and the correlation with marine terraces suggest them to be around 0.8 and 1.1-1.2 Ma old respectively. This study shows that not all sea level high stands are preserved in the stratigraphical and geomorphological record.
\end{abstract} Izvleček

UDK 551.435.8:551.468(450.82)"628.62"

Rosario Ruggieri \& Jo De Waele: Spodnje do srednje pleistocenske jame tipa flank margin pri Custonaci (Trapani, SZ Sicilija) in spreminjanje morske gladine

Za polotok San Vito Lo Capo $50 \mathrm{~km}$ zahodno od Palerma so značilne številne sledi preteklega spreminjanja morske gladine: morske terase, niše, morske in obalne jame s freatičnimi prerastki na sigi ter kopenski in morski sedimenti. Na osnovi izjemno ohranjenih oblik in sedimentov, so v preteklosti različni avtorji določili spreminjanje morskega nivoja in neotektonske premike. Med številnimi obravnavanimi jamami jih je večina morskega izvora, z ohranjenimi nišami in morskimi oz. kopenskimi sedimenti. Dve jami, Fantasma in Falesia Rocca Rumena I, pa kažeta značilnosti jam tipa flank margin. Obe jami imata sledove dviganja in spuščanja morske gladine. Njun položaj, z ozirom na morske terase, kaže na starost med 0,8 in 1,1-1,2 Ma. Naša študija pokaže, da v stratigrafskem in geomorfološkem zapisu niso ohranjeni vsi visoki nivoji morske gladine.

Ključne besede: telogenetski apnenec, obalni kras,speleogeneza $\mathrm{v}$ območju mešanja, spremembe morske gladine, kvartar.

Keywords: telogenetic limestones, coastal karst, mixing zone speleogenesis, sea level changes, Quaternary.

\footnotetext{
${ }^{1}$ Centro Ibleo di Ricerche Speleo-Idrogeologiche, Via Carducci 165, Ragusa, Italy, e-mail: info@cirs-ragusa.org.

${ }^{2}$ University of Nova Gorica

${ }^{3}$ Italian Institute of Speleology, Department of Biological, Geological and Environmental Sciences, Via Zamboni 67,

40126 Bologna, Italy, e-mail: jo.dewaele@unibo.it

* Corresponding author
}

Received/Prejeto: 02.10.2012 


\section{INTRODUCTION}

Carbonate coasts are among the most important littoral landscapes where geomorphological evidences of past sea level oscillations and stillstands are likely to be preserved better than in other lithologies. Unlike in other rocks, limestones exhibit a set of typical landforms that are shaped at or close to sea level, such as notches and caves, and morphologies related to biocorrosion (e.g. lithophaga borings) or bioconstruction (e.g. vermetid reefs) in the intertidal range. Together with other sea level indicators such as marine terraces, continental and marine sediments, this extremely various set of geomorphological markers allows these coastal carbonate areas to be used worldwide for sea level reconstructions (Lambeck et al. 2004; Suric et al. 2005; 2009; Dorale et al. 2010; Tuccimei et al. 2010; van Hengstum et al. 2011).

Also solutional caves can indicate the position of sea level at the time of their formation (Mylroie \& Carew 1988; Florea et al. 2007). There are four types of caves that can form at or near a relatively stable sea level: littoral caves (also called sea caves), conduit-flow stream caves, flank margin caves (Mylroie et al. 2008), and "Quintana Roo"-type mixing dissolution caves (Smart et al. 2006). The first caves form by wave action within the tidal range, causing mechanical breakdown and erosion of almost any type of rock. The wave energy exploits weaknesses in the rock mass, and chemical action of saltwater and compression of air through cracks and voids can increase the destructive action of the waves. Conduitflow stream caves are formed by inland waters that flow underground reaching the sea in subterranean estuaries. Nice examples of such caves are the Puerto Princesa Subterranean River in Palawan, Philippines (Piccini \& Iandelli 2011), Bue Marino and Bel Torrente caves in the Gulf of Orosei (De Waele 2004; De Waele et al. 2009), just to name a few. Many of these caves are now underwater, since these rivers tend to carve their floors in response to sea level drops. Their floors are also often covered with sediments that hide the original bedrock.
In many cases the elevation of the caves itself is not a reliable sea level indicator, but the erosional and corrosional features within the passages might give a closer approximation of past sea level. Especially close to the sea, notches formed in the tidal range, or biocorrosion marks (e.g. lithophaga borings) can be good indicators of past mean sea level (Carobene 1978; Carobene \& Pasini 1982; Furlani et al. 2011; Evelpidou et al. 2012). Flank margin caves form at the top and the bottom of the freshwater lens in coastal karst areas by mixing dissolution (Mylroie \& Carew 1990). This very special type of caves has been reported especially in eogenetic limestones of carbonate islands such as the Bahamas and Bermuda (Mylroie et al. 1995), Guam (Mylroie et al. 2001), the Mariana Islands (Jenson et al. 2006), and in Kangaroo Island, Australia (Mylroie \& Mylroie 2009), but also in mature limestones of New Zealand (Mylroie et al. 2008), in carbonate talus breccia on the Island of Cres in Croatia (Otoničar et al. 2010). Flank margin caves are much more reliable sea level indicators than coastal conduit-flow stream caves, showing clear evidence of dissolution at the fresh-salt water boundary, often very close to sea level, especially in areas where fresh water lenses are thin.

"Quintana Roo"-type caves represent an intermediate between true flank margin and epigene conduit-flow stream caves. Close to the coast the pattern is typically anostomosing, and sometimes spongework and ramiform, due to extensive mixing-corrosion processes, while in the upstream part the passages are typically dendritic, similar to conduit-flow stream caves. In these caves dissolution is driven by mixing of fresh and saline water over a very wide coastal zone (Smart et al. 2006).

In this paper we describe two flank margin caves, located 100 and $70 \mathrm{~m}$ a.s.l. respectively, constraining their timing of formation based on a series of correlations with dated marine terraces, geomorphological observations, and dated speleothems and their phreatic biogenic overgrowths.

\section{STUDY AREA}

San Vito Lo Capo is a peninsula that extends northward into the Tyrrhenian sea for about $10 \mathrm{~km}$, between Trapani and Palermo (NW Sicily) (Fig. 1).

The geology of the area is characterised by a series of two east and southeast oriented stacked tectonic units overthrusted one upon the other. These units have been formed during the collisional tectonics that characteri- sed this area from Lower Miocene to Middle Pleistocene (Abate et al. 1991, 1993; Catalano et al. 2011). Rocks are mostly composed of Mesozoic dolostones, limestones and dolomitic limestones, and Eocene-Miocene limestones, marly limestones, marls and clays. Since Upper Pliocene the region is slowly uplifting and fragmenting the area in blocks along NW-SE, N-S, and NE-SW faults. 

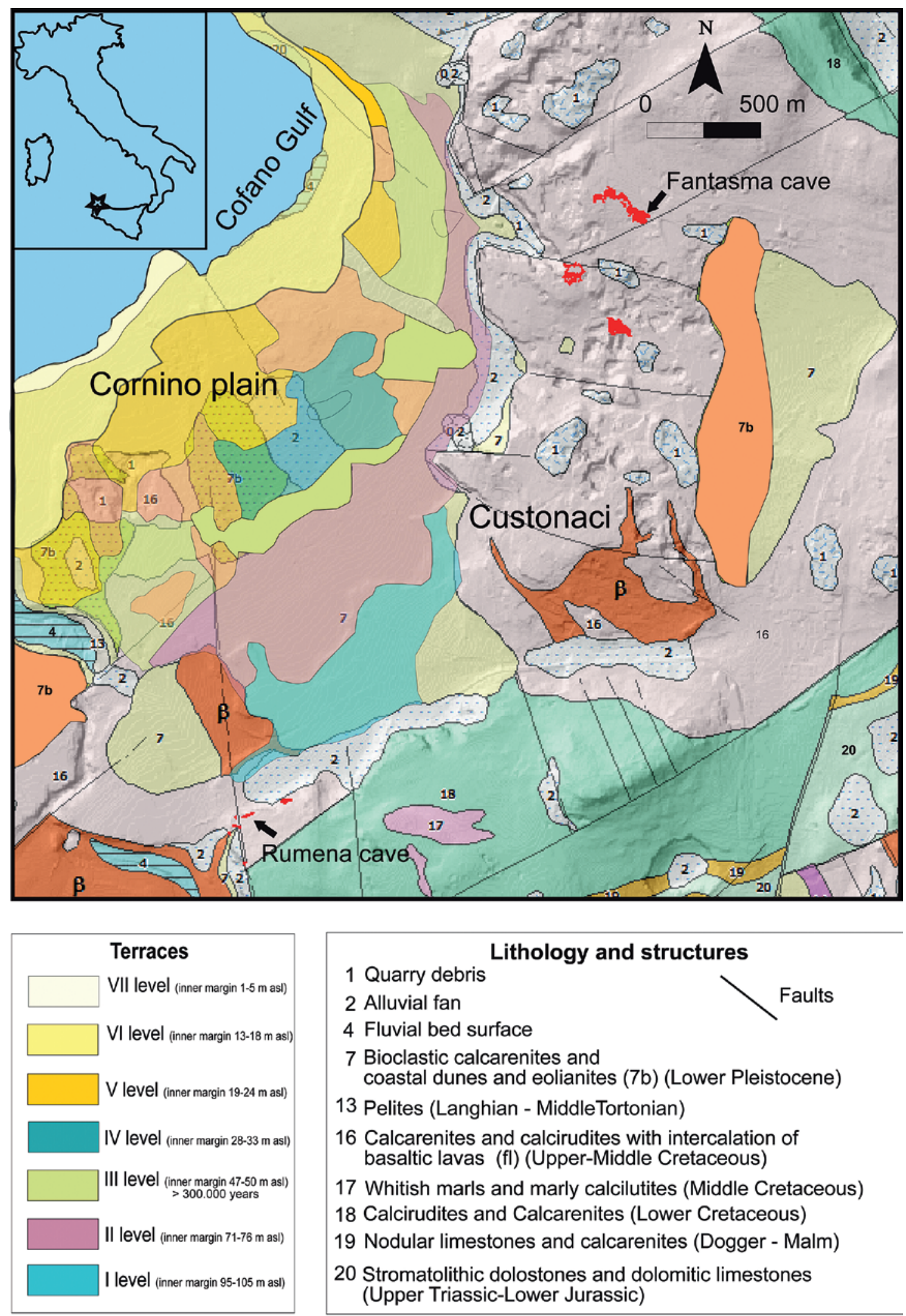

1 Quarry debris

2 Alluvial fan

4 Fluvial bed surface

7 Bioclastic calcarenites and

coastal dunes and eolianites (7b) (Lower Pleistocene)

13 Pelites (Langhian - MiddleTortonian)

16 Calcarenites and calcirudites with intercalation of basaltic lavas (fl) (Upper-Middle Cretaceous)

17 Whitish marls and marly calcilutites (Middle Cretaceous)

18 Calcirudites and Calcarenites (Lower Cretaceous)

19 Nodular limestones and calcarenites (Dogger - Malm)

20 Stromatolithic dolostones and dolomitic limestones (Upper Triassic-Lower Jurassic)

Fig. 1: Geology of the study area and location of the mentioned caves (from Di Maggio et al. 1999). 

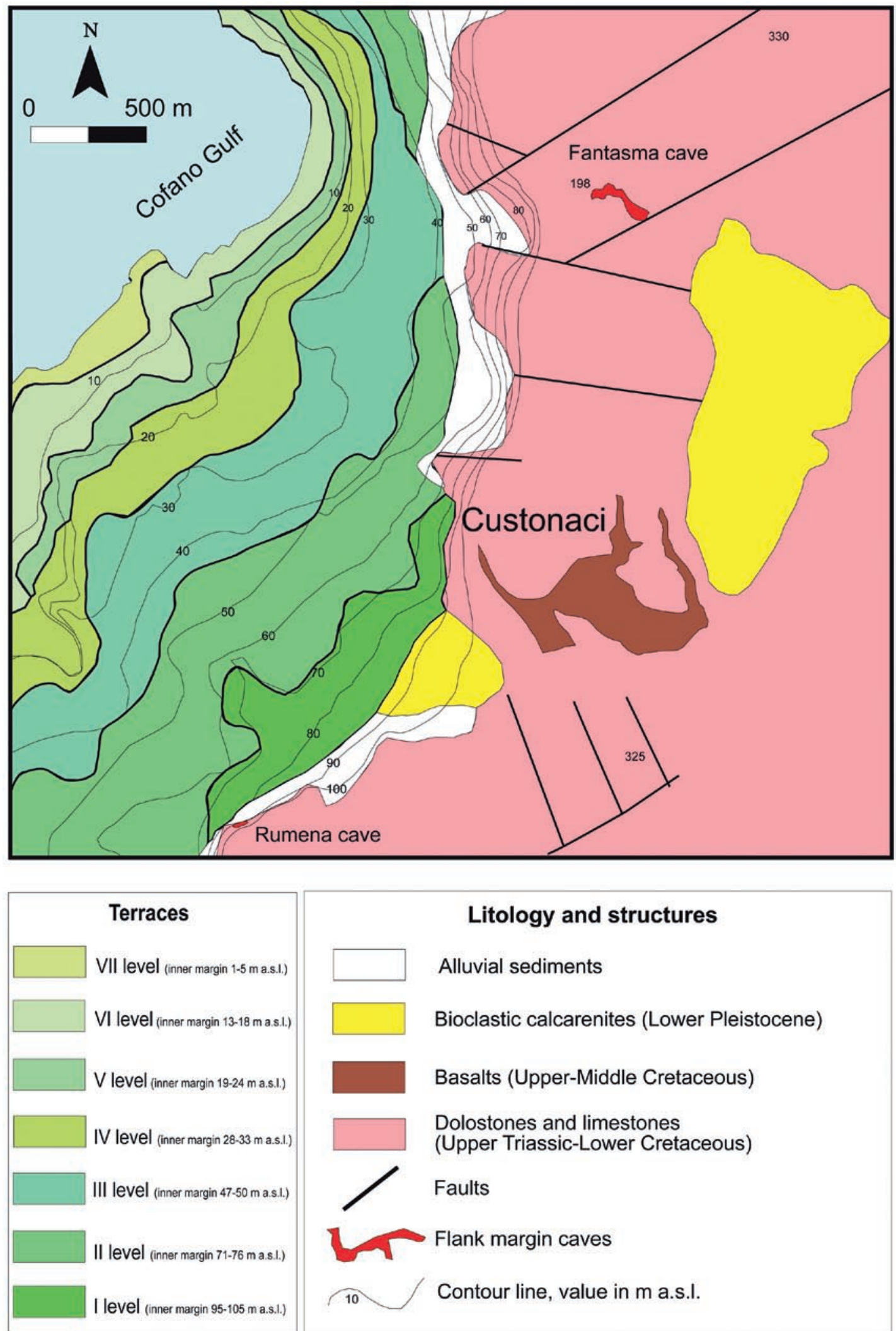

\section{Litology and structures}

Alluvial sediments

Bioclastic calcarenites (Lower Pleistocene)

Basalts (Upper-Middle Cretaceous)

Dolostones and limestones

(Upper Triassic-Lower Cretaceous)

Faults

1 Flank margin caves

10 Contour line, value in $\mathrm{m}$ a.s.I.

Fig. 2: Simplified geological scheme of the San Vito Lo Capo peninsula (modified from Di Maggio et al. 1999). 
The tectonic activity of the last $500 \mathrm{ka}$ is expressed by dislocation along normal and wrench faults of Middle Pleistocene and younger marine deposits outcropping at different altitudes along the coastal plain (Abate et al. 1993; Nigro \& Renda 2002). Extensive continental, transitional, and marine Pleistocene deposits, mostly composed of calcarenites (Di Maggio et al. 1999), are present along the coastal plains.

The Cornino-Custonaci Plain, where both Fantasma and Rocca Rumena I caves are located (Ruggieri \& Messina Panfalone 2011), is surrounded by high cliffs of Cretaceous limestones (Fig. 1). Seven marine terraces are present between altitudes of 0 and $105 \mathrm{~m}$ a.s.l. (Di Maggio et al. 1999) (Fig. 2). The age of these terraces has been estimated based on stratigraphical and paleontological evidences. The marine terrace VI, with upper boundary at 13-18 $\mathrm{m}$ a.s.l., contains the typical warm fauna with Strombus bubonius and can be attributed to MIS 5e. A speleothem sampled at $8 \mathrm{~m}$ a.sl. in a notch related to this terrace at San Vito Lo Capo has given a U/Th age of $19,625 \pm 5,300$ years $\mathrm{BP}$, confirming this terrace to be older than the Last Glacial Maximum (LGM) (Antonioli et al. 1999a). The presence of Elephas falconeri in some continental deposits at elevations higher than $40 \mathrm{~m}$ a.s.l., roughly corresponding to terraces III or IV, confirms their age comprised between MIS 9 and 17 (Di Maggio et al. 1999). A speleothem that covered the notch at $42 \mathrm{~m}$ a.s.l. at San Vito Lo Capo is beyond the U/Th radiometric dating method and indicates terrace III to be older than 300 ka BP (Antonioli et al. 1999a). Based on these abovementioned observations, terrace VII has thus be related to MIS $5 \mathrm{a}$ or $5 c$, while terrace $\mathrm{V}$ was attributed to MIS 7, terrace IV to MIS 9, terrace III to MIS 11, terrace II to MIS 13, and finally the highest terrace to MIS 15 or older. There is a possibility that some of these highstands have erased the traces of marine terraces or deposits, shifting the terraces to older interglacial intervals. It can therefore not be excluded that the highest terrace is related to MIS 15 or even older.

\section{CAVE MORPHOLOGY}

Many caves are known in the Cretaceous limestones surrounding the Cornino plain, but only some of these caves show evidences of past sea levels. The most interesting of these are the Fantasma and Falesia Rocca Rumena I caves (Fig. 3).

Fantasma Cave opens at $198 \mathrm{~m}$ a.s.l. in the area of Contrada Marcato Gnarosa, intensively exploited for its "marbles" in several quarries. The cave has clearly formed along two main fault systems, the first striking NESW with inclination of $75^{\circ}$ toward the SE, on which the entire first part of the cave is developed, and the second with WNW-ESE direction and dipping $80^{\circ}$ toward the SSW that influences the deepest part of the cave. While the first part is characterised by narrow fissure-like dissolutionally widened voids descending rapidly and with many indices of recent tectonic activity (broken columns and deflected stalagmites), at $120 \mathrm{~m}$ depth (around $80 \mathrm{~m}$ a.s.l.) the cave starts to show wall rock features such as rounded passages and cupolas characteristic for dissolution in phreatic conditions. Ten metres lower these metre wide tubes end in a large room called "Sala del Fantasma". This room has an ellyptical shape, is $50 \mathrm{~m}$ long and $25 \mathrm{~m}$ wide and has a height between around 6 and $10 \mathrm{~m}$. Its central part is occupied by a large heap of old bat guano, and large white and corroded speleothems stand out from the dark background (Fig. 4A). The northern part of this chamber is formed along a WNW-ESE fault with reddish mylonite (Fig. 4C), creating a perfectly straight wall up to $10 \mathrm{~m}$ high (Fig. 3A).

In general the roof and walls have extremely well rounded shapes, and at around $70 \mathrm{~m}$ a.s.l. the walls are perforated by up to several decimetre wide rounded tubes, forming a sort of perfectly horizontal notch (Fig. 4B-C). At the same altitude several metre wide rounded passages create loops on the southeastern side of the main chamber. Some of these passages tend to taper out and terminate with dead ends toward the East. The room is decorated with large calcite speleothems such as stalagmites, columns and stalactites. Most of these are intensively corroded, and are covered with an over $1 \mathrm{~cm}$ thick layer of white powder. These corrosion phenomena are most intense at $70 \mathrm{~m}$ a.s.l., corresponding to the altitude of the aforementioned notch. The general corrosion of cave walls and speleothems, very intense around and above the guano heap, is probably related to condensation water created by the slow exothermic transformation of the bat guano. The presence of taranakite $\left[\mathrm{H}_{6} \mathrm{~K}_{3} \mathrm{Al}_{5}\left(\mathrm{PO}_{4}\right)_{8} \cdot 18 \mathrm{H}_{2} \mathrm{O}\right]$ and apatite $\left[\mathrm{Ca}_{5}\right.$ $\left.\left(\mathrm{PO}_{4}\right)_{3} \cdot(\mathrm{OH})\right]$ show the guano to be relatively old and diagenised.

The major corrosion at $70 \mathrm{~m}$ a.s.l. along a perfectly horizontal plane indicates an influence of a stable water level. The guano-related condensation corrosion appears to be the most recent process, overprinting the older mi- 


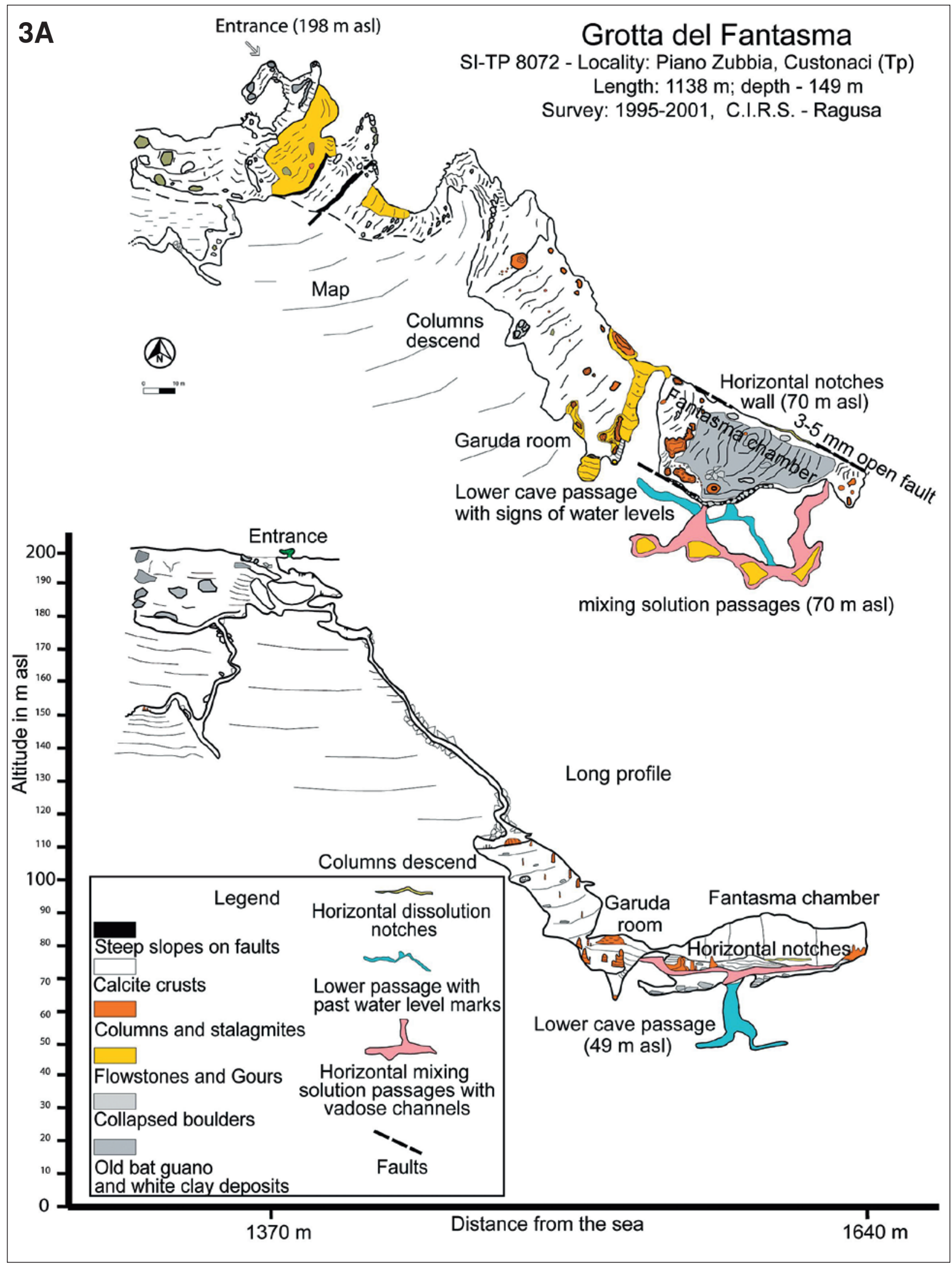

Fig. 3: Cave surveys: A) Fantasma cave B) Falesia Rocca Rumena I cave. 


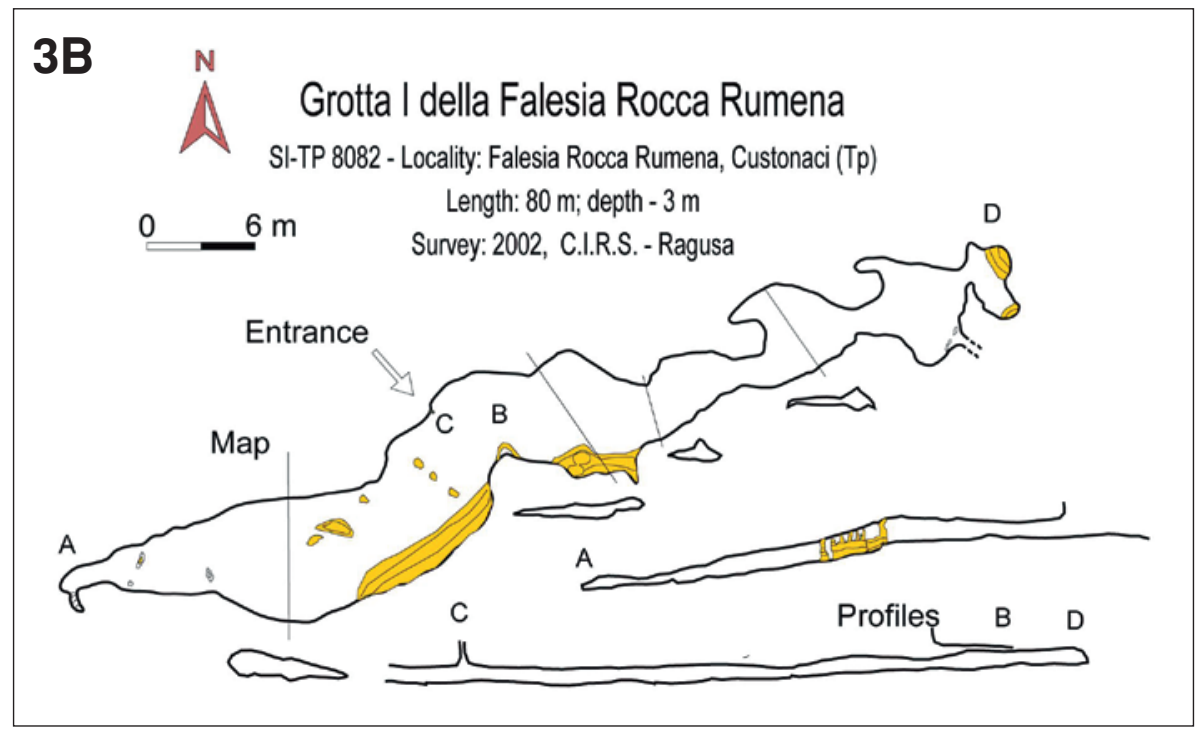

a.s.l. in correspondence of a not well-defined notch and a clear level of lithophaga borings. It is composed of a series of small chambers and passages with rounded forms, small tubes and pillars. The passages develop parallel to the cliff wall, mostly along fractures and bedding planes, but tend to tighten gradually going away from the cliff (Fig. 3B). The roof and part of the walls are covered with organogenic crusts, mostly scleractinian corals that also fill part of the lithophaga holes. Also speleothems are

xing corrosion phenomena. One small descending conduit develops 40 metres further towards SSW reaching an altitude of $49 \mathrm{~m}$ a.s.l. In this passage several traces of old water levels, visible as horizontally mud stained cave walls, are clearly recognisable (Antonioli \& Ruggieri 2000). Nowhere in the cave there are fluvial sediments, and the walls are always smooth and do not reveal any scallops or similar forms.

Grotta Falesia Rocca Rumena I is a small mostly horizontally developed cave formed at the foot of the $20 \mathrm{~m}$ high Pleistocene coastal cliff. Its entrance opens at $100 \mathrm{~m}$ covered with these corals and are perforated by lithophaga (Rosso et al. 2012). One stalactite in particular shows three growth hiatuses, suggesting submersion at least three times. U/Th dating of this stalactite were beyond the range of the method. The corals have been dated using ${ }^{87} \mathrm{Sr} /{ }^{86} \mathrm{Sr}$ ratio and appear to be $1,100 \pm 200 \mathrm{ka}$ years old (Antonioli et al. 2012). $\delta \mathrm{O}^{18}$ measurements on the continental stalactite layers and comparison with marine and continental records suggest this speleothem to be formed somewhere during MIS 31-37 (Antonioli et al. 2014).
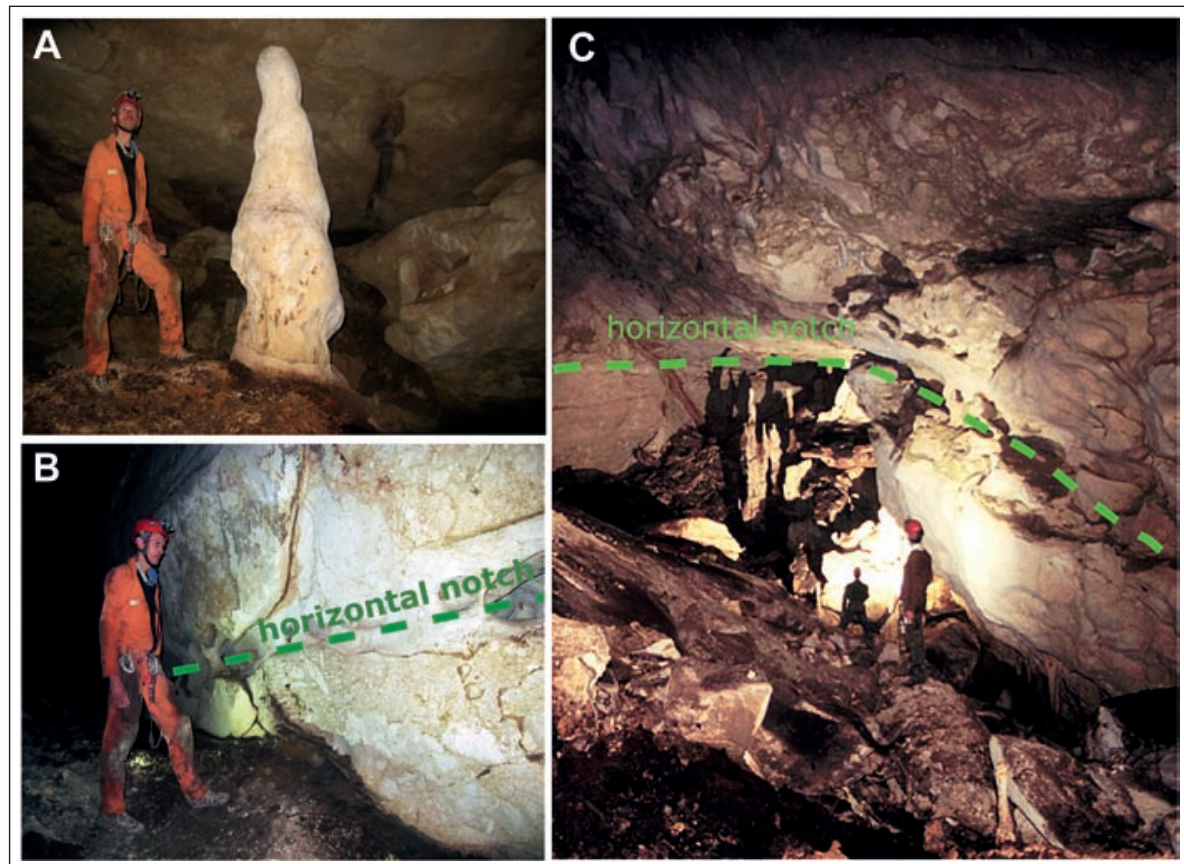

Fig. 4: Cave morphologies: a) The "Fantasma" speleothem, an old stalagmite modified by condensation-corrosion processes, probably related to organic decay of guano (dark material at its base); b) The very evident corrosion notch at $70 \mathrm{~m}$ a.s.l., that borders the entire Fantasma Chamber. These are formed by mixing corrosion at the former sea level. c) Panoramic view of the Fantasma Chamber looking East: the corrosion notches are clearly visible to the right ("swiss cheese" morphologies), while in the back of the room (left of the stalagmites) the reddish dark strip is the mylonite of the northern wall fault. Also note the abundant guano on the floor in the front of the picture (Photographs by Rosario Ruggieri). 

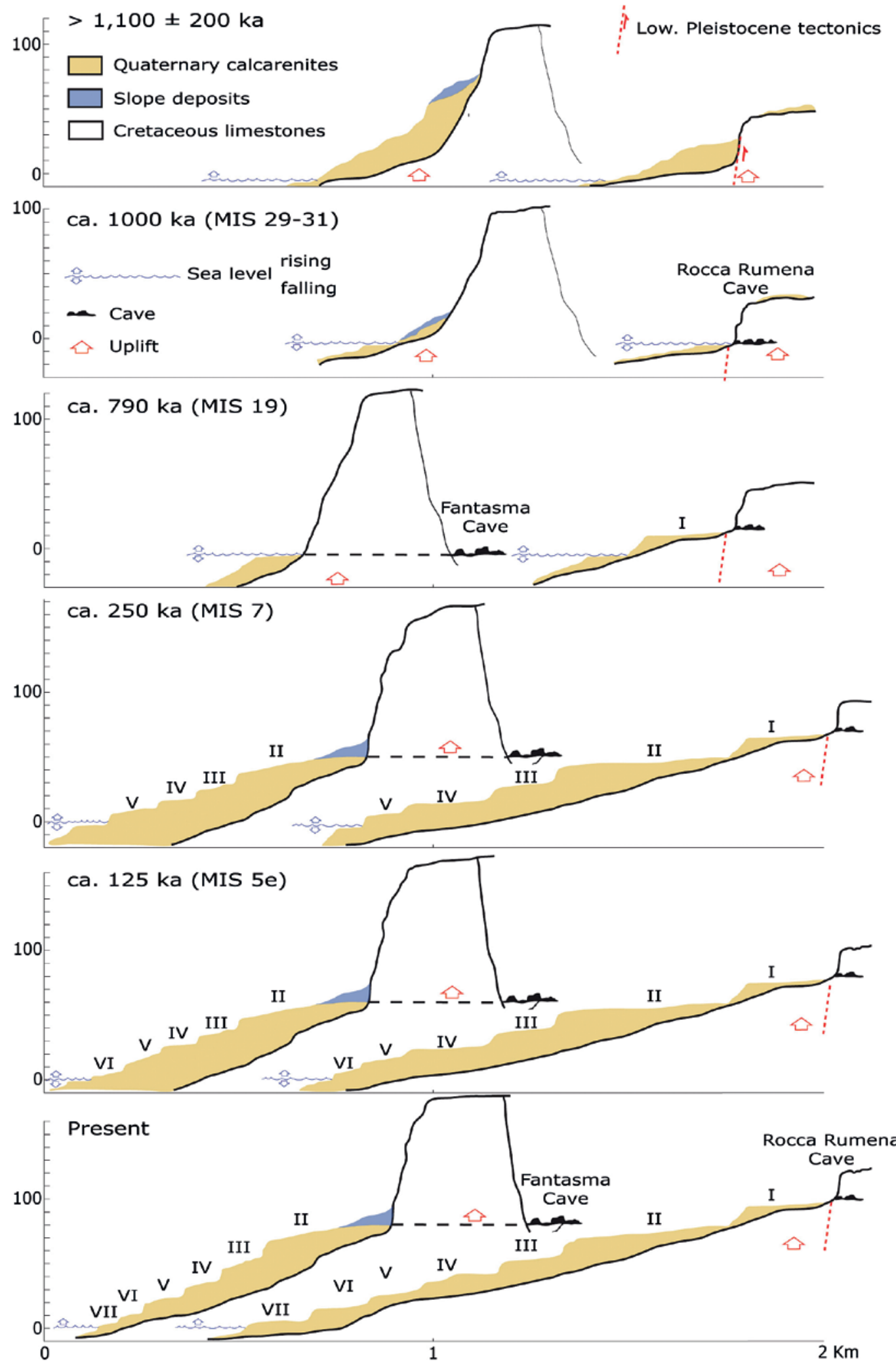

Fig. 5: Scheme showing the hypothesis of formation of the caves and the coastal terraces. See text for explanation. 


\section{DISCUSSION AND CONCLUSIONS}

The coastal area of NW- Sicily and San Vito Lo Capo in particular has been studied for over 20 years by many authors for the reconstruction of Pleistocene-Holocene sea level changes (Antonioli et al. 1994 Mauz et al. 1997; Antonioli et al. 1999a, 1999b; Di Maggio et al. 1999; Antonioli et al. 2002). The presence of a wide and various set of sea level markers, such as marine terraces, marine and continental sediments and their palaeontological contents, coastal caves, notches, lithophaga borings, etc., well preserved thanks to the relatively slow uplift rate of the entire peninsula, has made these reconstructions rather reliable. Also coastal caves show signs of past sea level still stands through the presence of typical corrosion features or biological markers (Antonioli \& Ruggieri 2000; Ruggieri 2013).

Many of the caves used for reconstruction of sea levels are marine caves, formed by the mechanical action of waves on fracture or bedding plane permeability pathways. Some of the caves, however, have typical morphologies of flank margin caves in telogenetic limestones (Mylroie et al. 2008). The lack of stream sediments and of stream flow morphologies such as scallops, and the typical morphology of interconnected rounded cave passages and chambers that tend to taper and terminate blindly going inland, confirm some of the coastal caves to be flank margin caves. The two described flank margin caves are especially interesting for the reconstruction of past sea level high stands (Fig. 5).

The Fantasma Cave is in reality an enlarged Middle Pleistocene - Holocene fissure that intercepts a Pleistocene flank margin cave at $80 \mathrm{~m}$ a.s.l. with signs of mixing corrosion down to $49 \mathrm{~m}$ a.s.l. The over 30 metre interval in which mixing corrosion seems to have operated in this cave is a sign of a rising (or falling) sea level over this range. In a slowly uplifting area it is more likely that the part of the cave with features related to mixing corrosion was developed during a period in which sea level stayed in this altitude interval for a long time, such as during the shift from rising to falling sea level, with a major stillstand. The main level of mixing corrosion, corresponding to the longest stable position of the sea level, is now located at $70 \mathrm{~m}$ a.s.l.
Falesia Rocca Rumena I cave is located at $100 \mathrm{~m}$ a.s.l., and based on the age of corals that cover its walls is older than $1,100 \pm 200 \mathrm{ka}$ (Antonioli et al. 2012). Since the cave itself, being a flank margin cave, developed at or near sea level, the coral age is a fairly good minimum estimate of the age of cave formation. The cave formed during an interglacial period, with relatively high sea level, probably during MIS 29 or MIS 31 (during which sea level was probably highest) (Shackleton 1995). Based on the stalactite, covered by the corals and showing at least three phases of growth interruption, the cave was probably close to sea level for a significant time span and experienced at least three subsequent subaerial and subaqueous phases (Antonioli et al. 2012, 2014).

This estimated age seems to indicate that not all sea level high stands have been preserved in the stratigraphical and geomorphological record in this area. This fact might easily be explained considering that the geomorphological and biological features related to less high stillstands have been subsequently entirely eroded during the higher sea-level stillstands. In the past million years this appears to have occurred at least twice, with two of the five interglacial stages between MIS 9-24 being undistinguishable or reworked in later deposits (Mauz et al. 1997).

To have a rough idea of the age of these caves we can use the tectonic uplift rates calculated using the MIS 5e notch and other geomorphological constraints ( $\mathrm{Di}$ Maggio et al. 1999). For the Cornino-Custonaci area the uplift rate is comprised between 0.07 and $0.11 \mathrm{~m} / \mathrm{ka}$. This rate is calculated using the estimated age of Falesia Rocca Rumena I cave 1100-1200 ka (MIS 29-31), actually located at $100 \mathrm{~m}$ a.s.l., and the elevation of the MIS 5e notch at $16 \mathrm{~m}$ a.s.l. Using these ages and an average uplift rate of $0.09 \mathrm{~mm} / \mathrm{ka}$, the horizontal maze-like chamber and conduits of Fantasma cave might thus have been created by the mixing corrosion of fresh and salt water probably around $780 \mathrm{ka}$ ago (ca. MIS 19). This means that half of the interglacial stages in the past $1200 \mathrm{ka}$ years did not leave clear signs in the coastal landscape, probably eroded by successive highstands.

\section{ACKNOWLEDGEMENTS}

Many thanks to Davide Vito Messina Panfalone for his logistical help and assistance during our cave expeditions to Custonaci. Mineralogical analysis of the Fantasma cave samples have been carried out by Prof. Ermanno
Galli from Modena and Reggio Emilia University. Suggestions and comments from Bojan Otoničar have been greatly appreciated. 


\section{REFERENCES}

Abate, B., Di Maggio, C., Incandela, A. \& P. Renda, 1991: Nuovi dati sulla geologia della penisola di Capo San Vito (Sicilia nord-occidentale).- Memorie della Società Geologica Italiana, 47, 15-25.

Abate, B., Di Maggio, C., Incandela, A. \& P. Renda, 1993: Carta geologica dei Monti di Capo San Vito, scale 1:25,000 (1:25,000): Dipartimento di Geologia e Geodesia, University of Palermo.

Antonioli, F. \& R. Ruggieri, 2000: Geomorfologia e speleogenesi nell'area carsica di Monte Palatimone (Custonaci, Tp) ed interconnessioni con il livello di base marino, I Seminario di Studi sul Carsismo negli Iblei e nell'area sud Meditterranea, Eremo della Giubiliana, Ragusa, 9-11 Aprile 1999, Centro Ibleo di Ricerche Speleo-Idrogeologiche Ragusa, p. 213-223, Ragusa.

Antonioli, F., Puglisi, C., Reitano, G. \& S. Tusa, 1994: Geomorphological evolution of S. Vito lo Capo promontory (Sicily, Italy) during Pleistocene: relationship between neotectonic, eustatism and prehistorical remains - Memorie descrittive della Carta Geologica d'Italia, 52, 337-360.

Antonioli, F., Cremona, G., Puglisi, C., Silenzi, S., Valpreda, E. \& V. Verubbi, 1999a: Quantitative assessment of post Tyrrhenian differential crustal movements in a Mediterranean coastal area (S. Vito-SicilyItaly).- Physics and Chemistry of the Earth Part aSolid Earth and Geodesy, 24, 343-347.

Antonioli, F., Silenzi, S., Vittori, E. \& C. Villani, 1999b: Sea level changes and tectonic mobility: precise measurements in three coastlines of Italy considered stable during the last 125 ky.- Physics and Chemistry of the Earth (A), 24, 337-342.

Antonioli, F., Cremona, G., Immordino, F., Puglisi, C., Romagnoli, C., Silenzi, S., Valpreda, E. \& V. Verrubbi, 2002: New data on the Holocenic sea-level rise in NW Sicily (Central Mediterranean Sea).- Global and Planetary Change, 34, 121-140.

Antonioli, F., Montagna, P., Caruso, A., Ruggieri, R., Lo Presti, V., Silenzi, S., Frank, N., Douville, E. \& C. Pierre, 2012: Investigation of marine and continental layers in a stalactite older than 1 million years (Custonaci, north-western sector of Sicily), SLALOM 2012, Athens 19-22 March 2012, p. 57-58, Athens.
Antonioli, F., Ruggieri, R., Montagna, P., Pepe, F., Caruso, A., Stocchi, P., Renda, P., Lo Presti, V., Frank, N., Douville, E., Pierre, C., Messina Panfalone, D., 2014: The geosite Rumena cave a unique paleoclimate and sea level archive in the Mediterranean area (north-western Sicily). In abstract $4^{\text {th }}$ International Symposium, Karst Geosites, Favignana 30 maggio - 2 giugno, 64-66.

Carobene, L., 1978: Valutazione di movimenti recenti mediante ricerche morfologiche su falesie e grotte marine del Golfo di Orosei.- Memorie della Società Geologica Italiana, 19, 641-649.

Carobene, L. \& G. C. Pasini, 1982: Contributo alla conoscenza del Pleistocene superiore e dell'Olocene del Golfo di Orosei (Sardegna orientale).- Bollettino della Società Adriatica di Scienze, 64, 5-35.

Catalano, R., Agate, M., Basilone, L., Di Maggio, C., Mancuso, M. \& A. Sulli, 2011: Note illustrative della Carta Geologica d'Italia alla scala 1:50.000, Foglio 593 Castellammare del Golfo. ISPRA, Servizio Geologico D'Italia, Roma.

De Waele, J., 2004: Geomorphologic evolution of a coastal karst: the Gulf of Orosei (Central-East Sardinia, Italy).- Acta Carsologica, 33, 37-54.

De Waele, J., Brook, G. A. \& A. Oertel, 2009: Monk Seal (Monachus Monachus) bones in Bel Torrente cave (Central-East Sardinia) and their paleogeographical significance.- Journal of Cave and Karst Studies, 71, 16-23.

Di Maggio, C., Incandela, A., Masini, F., Petruso, D., Renda, P., Simonelli, C. \& G. Boschian, 1999: Oscillazioni eustatiche, biocronologia dei depositi continentali quaternari e neotettonica nella Sicilia nord-occidentale (Penisola di San Vito Lo Capo Trapani).- Il Quaternario, 12, 25-50.

Dorale, J. A., Onac, B. P., Fornós, J. J., Ginés, J., Ginés, A., Tuccimei, P. \& D. W. Peate, 2010: Sea-Level Highstand 81,000 Years Ago in Mallorca.- Science, 327, $860-863$.

Evelpidou, N., Kampolis, I., Pirazzoli, P. A. \& A. Vassilopoulos, 2012: Global sea-level rise and the disappearance of tidal notches.- Global and Planetary Change, 92-93, 248-256.

Florea, L. J., Vacher, H. L., Donahue, B. \& D. Naar, 2007: Quaternary cave levels in peninsular Florida.- Quaternary Science Reviews, 26, 1344-1361.

Furlani, S., Cucchi, F., Biolchi, S. \& R. Odorico, 2011: Notches in the northern Adriatic Sea: genesis and development.- Quaternary International, 232, 158168 . 
Jenson, J. W., Keel, T. M., Mylroie, J. R., Mylroie, J. E., Stafford, K. W., Taborosi, D. \& C. Wexel, 2006: Karst of the Mariana Islands: The interaction of tectonics, glacio-eustasy, and freshwater/seawater mixing in island carbonates.- In: Harmon, R.S. \& Wicks, C.M. (eds.). Perspectives on Karst Geomorphology, Hydrology, and Geochemistry. Geological Society of America Special Paper, 404, 129-138, Boulder, Colorado.

Lambeck, K., Antonioli, F., Purcell, A. \& S. Silenzi, 2004: Sea-level change along the Italian coast for the past 10,000 yr.- Quaternary Science Reviews, 23, 15671598.

Mauz, B., Buccheri, G., Zoller, L. \& A. Greco, 1997: Middle to Upper Pleistocene morphostructural evolution of the NW-coast of Sicily: Thermoluminescence dating and palaeontological-stratigraphical evaluations of littoral deposits.- Palaeogeography Palaeoclimatology Palaeoecology, 128, 269-285.

Mylroie, J. E. \& J. L. Carew, 1988: Solution Conduits as Indicators of Late Quaternary Sea-Level Position.Quaternary Science Reviews, 7, 55-64.

Mylroie, J. E. \& J. L. Carew, 1990: The flank margin model for dissolution cave development in carbonate platforms.- Earth Surface Processes and Landforms, $15,413-424$.

Mylroie, J. E., Carew, J. L. \& H. L. Vacher, 1995: Karst development in the Bahamas and Bermuda.- In: $\mathrm{H}$. A. Curran \& B. White (eds.) Geological Society of America Special Paper. Geological Society of America, pp. 251-267, Boulder, Colorado.

Mylroie, J. E., Jenson, J. W., Taborosi, D., Jocson, J. M. U., Vann, D. T. \& C. Wexel, 2001: Karst features of Guam in terms of a general model of carbonate island karst.- Journal of Cave and Karst Studies, 63, 9-22.

Mylroie, J. E. \& J. R. Mylroie, 2009: Caves as Sea Level and Uplift Indicators, Kangaroo Island, South Australia.- Journal of Cave and Karst Studies, 71, 32-47.

Mylroie, J. E., Mylroie, J. R. \& C. S. Nelson, 2008: Flank margin cave development in telogenetic limestones of New Zealand.- Acta Carsologica, 37, 15-40.

Nigro, F. \& P. Renda, 2002: From Mesozoic extension to Tertiary collision: deformation patterns in the units of the North- Western Sicilian chain.- Bollettino della Società Geologica Italiana, 121, 87-97.

Otoničar, B., Buzjak, N., Mylroie, J. \& J. Mylroie, 2010: Flank Margin Cave Development in Carbonate Talus Breccia Facies: An Example from Cres Island, Croatia.- Acta Carsologica, 39, 79-91.
Piccini, L. \& N. Iandelli, 2011: Tectonic uplift, sea level changes and Plio-Pleistocene evolution of a coastal karst system: the Mount Saint Paul (Palawan, Philippines).- Earth Surface Processes and Landforms, 36, 594-609.

Rosso, A., Sanfilippo, R., Ruggieri, R., Maniscalco, R. \& A. Vertino, 2012: Associazioni di substrato roccioso da una grotta sottomarina del Pleistocene (Sicilia occidentale), Giornate di Paleontologia XII edizione, Catania 24-26 May 2012, p. 32-33, Catania.

Ruggieri, R. 2013: Speleological and Speleogenetic aspects of the Monti di Capo San Vito karst area (north-western Sicily): influence of morpho-tectonic evolution. $\mathrm{Ph}$. D. thesis, University of Nova Gorica, 300 pp.

Ruggieri, R. \& D. Messina Panfalone, 2011: Dentro e fuori la Montagna. Priulla, Palermo, pp. 182.

Shackleton, N.J., 1995: New data on the evolution of Pliocene climatic variability.- In: Vrba, E.S., Denton, G.H., Partridge, T.C. \& L.H. Burckle, (eds.) Paleoclimate and evolution with emphasis on human origins. Yale University Press, p. 242-248, New Haven.

Smart, P.L., Beddows, P.A., Coke, J., Doerr, S., Smith, S. \& F.F. Whitaker, 2006: Cave development on the Caribbean coast of the Yucatan Peninsula, Quintana Roo, Mexico. In: Harmon, R.S. \& C.M. Wicks, (eds.). Perspectives on Karst Geomorphology, Hydrology, and Geochemistry. Geological Society of America Special Paper, 404, 105-128, Boulder, Colorado.

Suric, M., Juracic, M., Horvatincic, N. \& I. K. Bronic, 2005: Late Pleistocene-Holocene sea-level rise and the pattern of coastal karst inundation: records from submerged speleothems along the Eastern Adriatic Coast (Croatia).- Marine Geology, 214, 163-175.

Suric, M., Richards, D. A., Hoffmann, D. L., Tibljas, D. \& M. Juracic, 2009: Sea-level change during MIS 5a based on submerged speleothems from the eastern Adriatic Sea (Croatia).- Marine Geology, 262, 6267.

Tuccimei, P., Soligo, M., Ginés, J., Ginés, A., Fornós, J., Kramers, J. \& I. M. Villa, 2010: Constraining Holocene sea levels using U-Th ages of phreatic overgrowths on speleothems from coastal caves in Mallorca (Western Mediterranean).- Earth Surface Processes and Landforms, 35, 782-790.

van Hengstum, P. J., Scott, D. B., Grocke, D. R. \& M. A. Charette, 2011: Sea level controls sedimentation and environments in coastal caves and sinkholes.Marine Geology, 286, 35-50. 